細菌の病原因子

司会のことば

島村 忠勝 (昭和大・医・細菌学)

笹川 千尋（東大医科研）

細菌感染症は細菌と宿主の相互関係の上に成り 立ち、細菌感染症の克服の為には、細菌の病原 因子と感染メカ二ズムの理解が重要であることは 今更言うまでもない。本学会では毎年の如く病原 因子に関するシンポジウムが行われており、最近 の研究の進歩により新しい病原因子が次々と 見い出され、その種類と機能の多様性には目を みはるものがある。感染における時々刻々と変化 する環境での細菌と宿主の相互応答がダイナミッ クに把握されるようになり、病原因子の理解が

一段と深まりつつある。

本シンポジウムでは、感染における環境変化に 対する細菌のストレス応答機構、宿主免疫機構に 影響を及ぼす菌体表在物質、細菌の細胞侵入に おける菌と宿主細胞の細胞間相互作用の分子機構 、細菌外毒素の新たな病原発現機構など、多岐に わたる話題が取り上げられる。その中から、 細菌の巧妙な生き残り戦略の一端を知り、それが 今後の病原因子研究のヒントとなり、また 細菌感染症の更なる理解につながれば、と考えて いる。

皆様とともに活発な討論が行なわれ、細菌の 病原因子について考える時間が共有できれば幸い である。 黄色ブドウ球菌におけるストレス応答の
調節系と生き残り戦略

太田敏子

（筑波大 $\cdot$ 基礎医・微生物）

細菌が不利な環境に置かれたとき、菌はその外 部環境の変化を感知し、その情報を細胞内へ伝え、 細菌の遺伝子発現と代謝系を制御して自己防衛し ている。その調節系は驚くほど多様性に富んでい る。しかも細菌は環境の変化に対応して、そのし くみを絶妙に変化させる柔軟性すら持ち合わせて いる。宿主内での感染成立は菌側にとっても大き な環境変化であり、ストレスとなる。このストレ ス応答機構を分子レベルで明らかにすることは、 病原性の発現を遺伝子レベルで解明し、その制压 に貢献する。グラム陽性菌では、まだストレス応 答機構の詳細は明らかにされていないため、我々 はこれまでS.aureusにおいて熱やアルカリなどの 環境ストレスに注目し、その調節系の解析を試み てきた。

S.aureusが 46 度の高温にさらされると、熱応 答した細胞では各種の熱ショック蛋白質 (HSP) の発現が一過性に細胞内で増強される。アルカリ にさらされた場合には、特異的なアルカリ応答蛋 白質 (ASP) がその役割を担っている。代表的な HSP70およびHSP60オペロンの上流域には尔によ る対数増殖期認識型プロモーター配列とCIRCE (Controlling IR of Chaperone Expression) 配列が認 められる。原子間力顕微鏡 (AFM) はCIRCE領 域亡相互作用する制御因子（ORF37）を明らかに した。また、和のクローニングにより、稀オペ ロンには熱応答プロモーターが認められた。一方、 ASPオペロン上流域には $\sigma^{28}\left(\sigma^{B}\right)$ による静止期認 識型プロモーター配列があり、アルカリに応答し ていた。環境変化に適応する分子機構は、特異的 な調節因子と転写を駆動するシグマ因子の選択に かかっているらしい。それはAgrやSarなどの調節 遺伝子による排出蛋白質の調節系とも異なってい る。しかも環境因子によりそのしくみも多様であ り、グラム陽性菌に特異的であることも解ってき た。S.aureusの生き残り戦略としての調節系のネッ トワークを解説する。 
歯周病原性細菌の病原因子

小川知彦

大阪大学歯学部口腔細菌学講座

口腔の慢性炎症性疾患である歯周病の発症や進行に かかわる病原性細菌としてグラム陰性桿菌群が注目さ れている。これら柬周病原性細菌の病原因子として, 付着因子（線毛，赤血球凝集素），内毒素，組織破壊 性酵素（コラゲナーゼ，トリプシン様酵素），細菌の 代謝産物（硫化水素，脂肪酸），白血球抵抗性因子

(莢膜，ロイコトキシン），免疫応答回避因子(免疫 応答抑制因子，免疫グロブリン開裂因子），運動性な どが報告されている。

我々は, 歯周病, なかでも成人性歯周炎の主たる原 因菌の一つと目されるPorphyromonas gingivalis の菌体 表層に位置する線維状構造体である線毛ならびに同菌 体の外膜の主要構成成分の一つであるリポ多糖体 (LPS) の活性発現の大部分を担っているリピドAの構 造とその活性について検討してきた.

$P$. gingivalis 線毛蛋白は歯周病巣局所において強い 免疫原性を発揮する。また，P. gingivalis 線毛ならび にその構成サブユニット蛋白を模して合成した部分合 成ペプチドを用いた解析の結果，体液性ならびに細胞 性免疫の誘導，B／T細胞エピトープ，サイトカイ ン産生誘導, 化学走性活性, マイトジェン作用, 多ク ローン性 B 細胞活性化作用，アジュバント作用，ヒト 歯肉線維芽細胞への結合ならびに刺激作用（本総会 別報) など多彩な免疫生物学的活性を発現することや その機能領域について明らかにした。これらの所見 から，P. gingivalis 線毛は多機能性蛋白であり，その 機能領域が同線毛サブユニット蛋白分子中に局在して いることが示唆される。

P. gingivalis 381株由来LPSの活性中心と考えられる リピドAを単離, 精製し, その化学構造を明らかにし た。その結果, 大腸菌ならびにサルモネラ由来のリピ ドA と比べ，4'位にリン酸基を持たず，2 位，2' 位に長鎖の分枝脂肪酸が結合している。 また，同りピ ドA は非常に低毒性でかつ種々の免疫薬理学的活性を 発揮する. 最近, P. gingivalis リピド A の低 IL-1 $\beta$ 産 生誘導には細胞内カルモジュリンキナーゼの活性化が 関与しているとの所見を得ており，敗血症性ショック などの予防や治療のための基礎情報になればと考えて いる。さらに, P. gingivalisリピドAは, Helicobacter pylon リピドAの構造パターンと類似し，しかも低毒 性であるという共通性を有し(本総会別報)，これら 慢性炎症性疾患を引き起こす病原性細菌のリピド $\mathrm{A}$ 構 造と活性という観点から興味がもたれ，炎症病巣の成 立やその慢性化の過程に刺激因子として関与している と考えられる。
ロドコッカス・エクイの病原性プラスミド

高井伸二

(北里大·獣医畜産・獣医衛生)

ロドコッカス・エクイ(Rhodococcus equi)は子 馬の化膿性肺炎の原因菌として獣医学領域では 古くから知られ、馬の飼育環境に広く分布する 土壤細菌である。医学領域でも稀な日和見感染 菌として報告されていたが、近年、AIDS患者に おいて結核との類症鑑別が難しい肺炎像を呈す 難治性のR. equi感染症の報告が増えている。私達 はこれまでにR. equiの毒力に関して、強毒株と無 毒株の存在、強毒株は毒力関連 $15-17 \mathrm{kDa}$ 抗原を 菌体表層に発現し、病原性プラスミドがこの遺 伝子をコードすること等を明らかにしてきた。 自然感染子馬の病変部分離株は $85 \mathrm{~kb}$ 或いは $90 \mathrm{~kb}$ の病原性プラスミドを保有する強毒株であり、 プラスミド脱落株はマウス及び仔馬に対する毒 力を失い、仔馬を用いた実験感染においても強 毒株のみが本症を再現できた。世界各国からヒ 卜AIDS患者由来株を集めて毒力関連抗原を検索 したところ、15-17 kDa抗原発現株と、毒力に関 連する新たな $20 \mathrm{kDa}$ 抗原を発現する株を見出した。 $20 \mathrm{kDa}$ 抗原発現株は強毒株に較べ約 10 倍のマウ ス $50 \%$ 致死菌量を示すことから中等度毒力株と 名付けた。中等度毒力株にも病原性プラスミド が存在し、プラスミド脱落株はマウスに対する 毒力が消失した。 $20 \mathrm{kDa}$ 抗原遺伝子の塩基配列が 決定され、15-17kDa抗原遺伝子との類似性 も明 らかとなった。ヒトの感染源を探るべく生活環 境土壤からの菌分離を行ったが、毒力関連抗原 発現株は全く分離されなかった。そこで過去に 分離報告のある豚下顎リンパ節を検索したとこ ろ、分離株の殆どが $20 \mathrm{kDa}$ 抗原発現株であること が明らかとなった。この中等度毒力株も経気道 実験感染で仔馬に肺膿瘍を形成した。本菌は仔 馬マクロファージ内での增殖像が病理組織学的 特徵とされる細胞内寄生菌である。食細胞内で の生き残り戦略は病原性プラスミドに規定され ているであろうが、どの様な食菌・殺菌抵抗性 機構が働いているのかは全く分かっていない。 最近、シャトルベクターを用いた形質転換が本 菌で可能となった。プラスミド上のビルレンス 因子の解析は将に始まったばかりである。 (共同研究者：関崎 勉、安斎了、和田隆一、 鎌田正信、斑目広郎、秋田 宰、下坂哲生、 田ノ上智章、佐々木由香子、椿 志郎) 
S - I - 4

神経伝達物質放出機構と クロストリジウム神経毒素

林 哲也 （信州大・医・細菌）

ボツリヌス毒素(AからG型)と破傷風毒素は、 神経終末において神経伝達物質の放出を阻害す る蛋白毒素である。これらはいずれものH鎖と L 鎖から構成され、さらに 1 次構造上も相同性 を有し、1つの毒素ファミリーを構成してい る。近年、これら神経毒の L 鎖が亜鉛依存性蛋 白質分解䣼素活性を持つことが明らかとなっ た。その基質として前シナプス膜蛋白質である syntaxin(C型毒素)、SNAP-25 (A,E,C型)とシ ナプス小胞の膜蛋白質synaptobrevin (破傷風 およびB,D,F,G型)が同定され、これら 3 種の蛋 白質がシナプス小胞の前シナプス膜への膜融合 に関与することが初めて示された。一方、細胞 内輸送小胞が標的膜に融合する過程に必須の可 溶性蛋白質SNAP/NSFのレセプター(SNARE) と してこの 3 者が同定され、これらが複合体

(SNARE 複合体)を形成することが示された。さ らに、種々の細胞内輸送小胞の膜融合に必須の 蛋白質として、この 3 者に相同性を有する蛋白 質群が醭母から高等生物に至るまで広く存在す ることも明らかとなった。これらの結果を基に 輸送小胞の標的膜への融合特異性は小胞および 標的膜上のSNAREの結合特異性によって規定さ れ、SNARE複合体の形成とそれに続く

SNAP/NSFによる複合体の解離が膜融合を引き 起こすというSNARE仮説が提唱された。

本シンポジウムでは、クロストリジウム神経 毒の研究とシナプス小胞をはじめとした細胞内 輸送小胞の膜融合の研究の流れの概要を紹介 し、SNARE 複合体の形成亡その性状、解離の 機構、およびクロストリジウム神経毒による 個々のSNARE 蛋白質切断のこれらの過程に及 ぼす影響について、演者らが組換え蛋白質を用 いた in vitro 再構成実験によって解析した結果 を紹介したい。なお、この演者らの研究は独連 邦動物ウイルス病研究所 H. Niemann教授の研 究室において、T. Binz博士、山崎伸二博士

（現、国際医療センター）らと共同で行ったも のである。
S - I - 5

赤痢菌の細胞侵入とシグナル伝達

○度会雅久、笹川千尋 $($ 東大医科研・細菌)
赤痢菌は腸上皮細胞との接触によって細胞 骨格系蛋白質の再構成を引き起こし、これに よってファゴサイトーシスを誘発し上皮細胞 の底面から細胞内へ侵入する。宿主細胞内で 菌は増殖・拡散し、これを通じて腸管組織に 炎症・潰瘍を誘起し最終的に血性下痢を惹起 する。本菌の細胞侵入から拡散に至る過程 は、菌の上皮細胞への接着、ファゴサイトー シスの誘発、ファゴゾームからの脱離、細胞 骨格線維の再構成によるアクチン重合を利用 した拡散から成る。従って本菌の感染過程に は菌と宿主細胞の様々な機能が関与し、それ らの複雑な相互作用により最終的に感染が成 立すると考えられる。しかし各感染過程にお ける菌と宿主細胞の正確な相互作用はまだ不 明な点が多い。

我々はこれまでにB群赤浰菌の大プラスミド 上の細胞侵入性遺伝子群の解析を行い、侵入 性蛋白質(IpaB, IpaC, IpaD) と、さらにそれらIpa 蛋白質の菌体外分泌を促す20数個のMxi, Spa蛋 白質が存在することを明らかにしてきた。ま たIpa蛋白質は菌と上皮細胞との接触により、 菌体表層結合型から遊離型となり外液中へ多 量に放出されること、この遊離型Ipa蛋白質は $\alpha_{5} \beta_{1}$ インテグリンに結合し、これによって宿主 細胞内蛋白質のチロシンリン酸化が促進され ること、さらに本菌の細胞侵入に伴うシグナ ル伝達が低分子量G蛋白質Rhoによって制御さ れていることを見い出した。

そこで今回、赤痢菌の細胞侵入初期過程に おける菌と宿主細胞間の相互作用を中心に、 赤痢菌感染の分子機構について考察したい。 


\section{S - I - 6}

コレラ菌エルトール溶血毒は病原因子か

○生貝 初、島村忠勝 (昭和大・医・細菌学)

コレラ菌エルトール溶血毒(ETH)は種々の動物 赤血球に対する溶血、培養細胞やマウスリンパ球 に対する細胞傷害、マウスに対する致死活性を持っ ている。ETHの分子レベルでの研究は1970年代後 半から1990年代前半にかけて行われ、その中で KaperらのグループはETHがコレラの病原性に関 連性のないことを報告した。しかしながら、コレ ラ毒素非産生のVibrio cholerae O1による下痢症が 存在することや、ETHと同一のものとみなされて いるV. cholerae non-O1の産生するエルトール様溶 血毒がV. cholerae non-O1による下痢症に関与して いる可能性が示唆されている。従って、現在もこ れらの細胞傷害性溶血毒はV. cholerae O1やnon-O1 による下痢症の病原性因子の一つとして疑われて いる。

我々はETHの)毒性が標的細胞の膜上に $65 \mathrm{kDa}$ の 毒素単量体の孔状集合体形成を原因とする膜傷害 によって発現されることを明らかにした。孔形成 能を持つETHは $65 \mathrm{kDa}$ げではなく、C末端側か ら約 $10 \mathrm{kDa}$ のころで切断された約 $55 \mathrm{kDa}$ の分子 量を持つものも存在する。ETHは170から350kDa の分子量を持つ10個前後の集合体が膜上に形成さ れるという興味深い性質があるが、全ての集合体 が孔を形成しているかどうかは今のところ明らか にされていない。このような孔形成毒素を産生す る細菌が生体に感染した時、直接的に細胞や組織 に傷害を与えるだけでなく、生体反応を調節する 機構にも作用し、間接的に生体に影響を与える可 能性があることが示唆されている。ここでは、最 初にETHの膜上での集合体形成とその集合体孔の 物理化学的性質についてふれ、さらに本来細胞傷 害を起こさない微量のETHとコレラ菌が産生した 他の因子が協同的に関わって細胞傷害が引き起こ されることを紹介し、ETHの病原性について考え てみたい。

\section{S - II}

感染症の最近の問題点 :

基礎と臨床の接点を探る

司会

\author{
外山圭助（東医大-..内） \\ 山口惠三（東邦大・微生物）
}

環境衛生と抗生物質の発達は、臨床の場から感 染症を一掃した感があったが、実際には形を変え てしたたかに存続し、最近では新たな問題を提供 する感染症も出現している。

本シンポジウムでは現在問題となっている感染 症を取りあげ、これらの感染症がなぜ問題となっ ており、どのように対処すればよいのかなどにつ いて、基礎領域の研究者と臨床医が共同で解決に あたる足がかりを提供することを目的とした。

まず最初に、耐性菌感染症を取りあげた。

penicillinは従来肺炎球菌に対しては優れた抗菌 力を示し特効薬として用いられてきたが、最近PC 耐性菌が出現し、本菌による感染症が治療上重要 な話題となっている。また、最近欧米で問題視さ れているvancomycin耐性晹球菌は、近い将来に本 邦においても臨床上大きな問題となる事は必至で ある。methicillin耐性ブドウ球菌感染症は一時は社 会的にも大問題となり注目を浴びた。しかし、現 在もこの感染症の対策は完全に解決したとは言え ず、依然として多くの病院で跈療上問題になって いる。

Helicobacter pylorii 胃潰瘍の関係は周知の事実 であるが、WHOによってH. pyloriiが胃癌のリスク 因子であろうといら警告が発せられてから、その 関係が注目されるようになった。また、最近一部 のBリンパ腫の発症にH.pyloriiが関係する事が判明 したが、これらの機序は明らかではない。

真菌感染は、抗癌化学療法の発達に伴う免疫不 全患者やHIV感染症患者の增加とともに問題となっ ており、その早期診断拉よび治燎法の確立が望ま れている。

海外との交流の增加は、新たな外来伝染病の問 題を発生させた。特にマラリアは古い疾患である が、臨床矤の関心・知識の薄さから、国内におけ る診療の現状は極めて貧弱である。 


\section{S - II - 1}

$$
\begin{gathered}
\text { ペニシリン耐性肺炎球菌 (PRSP) } \\
\text { 一肺炎を中心に一 }
\end{gathered}
$$

舘田一博（東邦大・微生物）

肺炎球菌はその強い病原性から依然として 肺炎、敗血症、髄膜炎などの感染症の重要な起 炎菌の 1 つである。本菌はペニシリンに対して 高感受性を示していたが、最近ではペニシリン 耐性株(PRSP)の増加が世界的な問題となって いる。本邦においても1980年代後半からPRSP の分離率は次第に増加し、1994年では全肺炎球 菌の $40 \%$ 以上がPRSPであったとの報告もみら れる。幸いにも、現在のところそのMICは1-2 $\mu \mathrm{g} / \mathrm{m}$ 程度であり、臨床においても治療失敗例 の報告は多くない。しかし、今後さらに耐性度 が高まる可能性も充分に考えられることから、 現時点においてその病原性、治療法について再 検討しておくことが賢明である。

我々は、CBA/JマウスがPRSPに対して感 受性が高く、本マウスを用いることにより健常 人に発症するPRSP肺炎を再現できることを報 告した。今回、このマウス肺炎モデルを用いて、 如何なる抗菌薬療法が本菌肺炎に対して有効で あるのか、PRSP感染症では本当にペニシリン は無効なのか、などの疑問点について報告する。 特にペニシリン系抗菌薬ではin vitroとin vivo効 果の乘㕍がみられることから、その理由につい ても解析を加える。

また第二点として、このマウス肺炎モデル を用いて、CBA/JマウスがなぜPRSPに感受性 が高いのか、PRSPの病原性は感性株と同等か、 肺炎発症におけるサイトカインの関与などにつ いても報告する予定である。特に本菌感染症に おいては、その発症にTNF、IL-1などの炎症性 サイトカイン、PAF、補体などの関与が報告さ れている。肺炎発症時にこれらメディエーター が如何なる動態を示すのかを検討することによ り、本菌感染症の発症機序について考察する。

\section{S - II - 2}

\author{
腸球菌の高度薬剤耐性および病原性因子 \\ と高頻度接合伝達性プラスミド
}
○池 康嘉 ${ }^{1,2}$ 、谷本弘 $-^{1}$ 、藤本修平 ${ }^{1}$ 、 富田治芳 ${ }^{1}$ 、小沢良之 ${ }^{1}$ （群馬大・医・ 1 微生物、2 薬剤耐性菌実験施設)

臨床分離腸球菌の主な菌種は E. faecalis と $E$. faecium である。これらの菌はすべての抗生物質 に対して獲得耐性となり得る。重症院内感染原因 腸球菌はペニシリン、高度ゲンタマイシン、バン コマイシン耐性菌である。我が国では現在までに これらの耐性菌による重症院内感染は報告されて いない。我々の研究では臨床分離 E. faecalis の約 30〜40\%は高度ゲンタマイシン耐性で、最近 1 例 ではあるが E. faecium の多剂耐性バンコマイシ ン耐性菌が人感染症から分離されている。その他 E. faecalis からテトラサイクリン耐性（約 80\%)、 エリスロマイシン耐性(40\%)が高頻度に分離され ることが特徵である。臨床分離腸球菌 (E. faecalis) の多くは病原性因子の蛋白分解酵素 $(\mathrm{Gel}) 、 \beta$-溶血 毒素 ( $\beta$-Hly)、紫外線耐性(UVR)、バクテリオシ ン(Bac)を保持している。 $\beta$-Hly/UVR は約 40〜 $50 \%$, Bac は約 $80 \%$ の菌が生産する。Bac はその 抗菌域から 4 種の型が存在する。腸球菌において 特徴的なことは、これら各種の形質がグラム陽性 菌で唯一の高頻度接合伝達性プラスミド上に存在 することである。その他、接合伝達性トランスポ ゾン $\left(\mathrm{Tc}^{\mathrm{r}}\right) 、 \mathrm{Tn} 3$ 型トランスポゾン $\left(\mathrm{Em}^{\mathrm{r}}, \mathrm{V} \mathrm{an}{ }^{\mathrm{r}}\right)$ 等 の上にも存在しこれらの形質の拡がりに関与して いる。E. faecalis の高頻度接合伝達性プラスミド の接合伝達には細菌では唯一のフェロモンが関与 する。E. faecalis 受容菌は 7、8 個のアミノ酸の ペプチド（フェロモン）を分泌し、プラスミドを 保持する供与菌はフェロモンに反応し、その菌体 表面に凝集物質を生産し供与菌、受容菌は接合凝 集を行い、プラスミドが高頻度に伝達される。フ エロモンに反応する分子遺伝学的調節機構は、プ ラスミド $\mathrm{pAD} 1(58 \mathrm{~kb}), \mathrm{pPD} 1(60 \mathrm{~kb}), \mathrm{pCF} 10$ $(58 \mathrm{~kb})$ において詳しく研究されている。プラスミ ドの約 $7 \mathrm{~kb}$ の領域にフェロモンに反応する遺伝子 が存在しオペロンを形成しており、これらの領域 の遺伝子はそれぞれお互いのプラスミドでよく保 存されている。E. faecium には高頻度接合伝達性 プラスミドは知られていなかったが最近、フェロ モンによらない新たな接合伝達機構による高頻度 接合伝達性プラスミドが発見された。 


\section{S - II - 3}

薬剂耐性黄色ブドウ球菌感染症の変貌

稲松孝思

東京都老人医療センター感染症科

抗菌薬の開発進歩は, 細菌感染症治療に画期的 な成果を上げ，人類に大きな福音を与えてきた. しかし, 黄色ブドウ球菌は, 次々之新開発の抗菌 薬に耐性を備え，この10数年はメチシリン耐性黄 色ブドウ球菌（MR S A ）が曼延し，メチシリン /セフェムのみならず, カルバペネム, ニューキ ノロン，ミノサイクリンにも次々と耐性化してき た．その耐性化のスピードは世界的に見て日本が 突出していたが，いくつかの国々がこれに追いつ きつつある. 臨床の現場ではバンコマイシン療法 などの抗MR S A 対策の普及により, 当初のパニ ック状態は鎮静化し，MR S Aが常在菌化しつつ あるなかで，MR S A感染症の発症による実害を 如何に最小限にするかと言った視点からの対応が なされつつある。 その一方でマスコミにより広ま った「MR S A 恐怖」がもたらした保菌者の過剩 差別問題屯深く医療福祉領域に蔓延している。 そ こで, 黄色ブドウ球菌の薬剂耐性化の歴史を振り 返り，当院における臨床症例の分析を基に，臨床 の立場から問題点を整理し，基礎研究の課題につ いて考えてみたい.

問題点は以下に要約できる. (1)黄色ブドウ球菌 は他の大部分の菌種と比較して，なぜ耐性化しや すいのか，その機序の解明により新たな耐性菌対 策はできないか. (2)耐性菌が蔓延／増加する機 序は交差感染，抗菌薬による選択的増殖，易感染 宿主の増加によると思われるが，その対策は？

(3)耐性化之病原性の関係は? (4)発症例を如何に 適切に治療可能か? - V C M 耐性への警戒, 新薬 の開発. (5)MR S A 常在菌化の必然性の中で, 無 症候性保菌者をどの様に扱えば良いのか?

将来に向かった対応の構築は，これらの問題を 解決することによりもたらされる筈である。
S - II - 4

臨床細菌検查における基礎と臨床の接点 - H. pylori 検査の経験から

信州大学医学部臨床検査医学 勝山 努

検查部に勤務するものにとって、最近十数年間 はとみに細菌学に親しむ機会が増している。緑滕 菌の出現以来、レジオネラ菌、MRSA，最近では H. pyloriや0-157と、次々に新顔が登場し、一 方ではPCRをはじめとする新しい診断法が導入さ れ、検査室はその対応に追われてきた。今回は H. pylori 検查における我々の経験を紹介した い。H. pylori は1983年胃炎、消化性溃瘍の原 因菌として始めて報告された新種のグラム陰性微 好気性螺旋菌である。今まで疾患であるかどうか さえ議諭の対象であった胃炎、ストレス学説の格 好の例とされた消化性潰瘍がいずれも感染症で あったというのだから、消化器病学の領域ではコ ペルニクス的轱回といってよい大事件であった。 したがって、発見当初からとくに臨床医の関心を 強く引きつけた。現在も除菌の方法諭の議諭が先 行し、細菌学も臨床細菌学も臨床医の後を追いか けるという傾向が続いている。

H. pylori の検查部レベルでの存在診断には、 生検標本からの培基のほか、病理組辂標本上での 確諗、血清抗体価の測定、13C urea breath test、ウレアーゼ遺伝子などをターゲットにし た遣伝子診断などがある。現在ではそれぞれの診 断法ともほぼ一定のレベルに到達し、一致率は 95\%を越える。分子生物学的な解析も進行して いるが、信頼できる型別法は未だ報告されていな い。pulsed field gel electrophoresisによる 型別の報告はあるが、松本によるとDNAのメチル 化により適切なDNAの断片化は困難である。胃と いう特殊な環境に棲息するきわめて興味深い細菌 であり、細菌学的な研究の進展に期待したい。 


\section{S - II - 5}

深在性真菌感染症にお忊る基礎と臨床

河野 茂（長崎大·医・第二内科）

深在性真菌症は一般に診断や治療が困難であ り、臨床病態に関しても真菌に対するアレルギー や器質的病変部におこる定着、 compromised host に発症する日和見感染症など多彩である。従って 臨床診断においては、血清診断法や遺伝子診断法 などを、また治療においてはDrug delivery system など基礎的な知識や技術を取り入れて、新しい試 みを行っている。さらに病態の解明には、真菌自 体の病原因子や宿主の生体防御反応など基礎と臨 床の接点と思われる領域の研究も盛んである。

本講演では肺アスペルキルルス症と肺クリフト コックス症に絞り、基礎と臨床の接点の概説を行 う。

肺クリプトコックス症は、健常人にも発症し、 関東以西から九州にかけて集中的に報告されてい る。Cryptococcus neoformansは沜の䔬や土壌など に生育し、乾燥により空気中に飛散して、経気道 的に吸引され、肺に病変を形成する。本邦でみら れるクリプトコックスはC. neoformans var.

neoformansであり、血清型も95\%はA型である。疫 学調査として、環境分離株と臨床分離株のgenome typeを比較することは、その感染経路を把握する ため極めて有用であり、RFLP法とAP-PCR法を用 いて検討したので報告する。本真菌の病原因子と して莢膜の重要性が知られている。臨床分離株と 肺胞マクロファージを用いて貪食率と莁膜の関連 を検討した。また、宿主の防御機構を検討するた

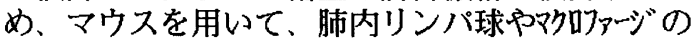
反応性の検討では、肺胞マクロファージを介した T細胞の活性化と、それに続くサイトカインネッ トワークの活性化がみられた。興味深いことに、 強毒株ではTh2系が活性化され、弱毒株ではTh1系 が活性化され、明らかに防御反応に相違が認めら れた。また、熱ショック蛋白のが本症の免疫反応 に関与していることが初めて明らかになった。

\section{S - II - 6}

マラリア

都立駒込病院・感染症科

增田㴊太
マラリア感染者は世界人口のうち $3-5$ 焦人、 死亡者数が每年 $150-300$ 万人とされ、䓡带 地方に多い疾患である。わが国では、近年、この 原虫感染症の国内発生が皆無に近く、しかも過去 数十年間にわたつて輪人症例数も少なかつた。そ のため本聅患の存在に対する認識が希溥であり、 発然を主症状として医療期間を受衫しても他の疢 患と誤韧されたり、さらに死亡者例も散兒される。

マラリアはわが国で次の点で重要である。(1)流 行地からの㷌国者間に見られる発然聇例のうちに 本疾患が混在している。(2)熱帯整マラリアは重篤 化しゃすい。(3)整带愁マラリア原虫は従来から使 用されてきたクロロキン製郕やファンシタールな どに対する耐性株が增加している。(4)三日䰻マラ リアではブリマキン刺性株が增加している。(5)渝 血、針差しなどの医燎行為、空港や旅客の手荷物 に関連したと考えられる症例が報告される。

ヒトに感染するマラリア原虫として治燎上最も 問題となるのが熱帯䓡マラリア原虫である。夥込 病院では本聅患を敏年 5 - 10 例経験しているが、 薬郕感受性試娩を行いえた原虫株の多くでク口ロ キン、ファンシダール酎性株が証明された（群馬 大学奇生虫学教室）。これらの症例に対しては主 としてメフロキンやキニーネが用いられ、いずれ も治糡に成功しでいるが、伐に、他の原虫種と讙 同定されて感受性でない蒋剤が選択されていたと すれば重症化、あるいは致死的となっていたこと が予想される。マラリア族例での原虫種の闹定が 重要であることが改めて強䜠される。 


\section{環境と微生物}

司会の言葉

青木 宙（東京水産大）

白井 誠（茨城大・農学部）

感染症の原因である病原微生物も生態系を構成 する生物の一つであり、環境の影響を強く受ける。 また様々な環境に適応して生育する微生物の中に はヒトに有害作用をもつ物質を産生するものがあ る。一方、微生物学の重要な意義の一つとして、 分子生物学あるいは分子遺伝学における新知見の 多くが微生物の研究から得られた事実がある。近 年、微生物の極限環境への適応に関する分子レベ ルの研究により、これらの分野における新たな知 見が次々と得られている。そこで本シンポジウム においては、特殊な環境に生育する微生物の生態 と環境適応、および環境変化に応じて発生した微 生物が産生する毒素についてご紹介いただく。

高温、高圧、強酸性あるいは強アルカリ性等の 極限環境条件下で生育可能な微生物の持つ普遍性 と多様性が、DNA 情報レベルで明らかになりつ つある。同じ極限環境条件下に存在する微生物は 種が異なっていてもその環境への応答機構に関す る遺伝子に共通性が見られ、また、環境変化に対 応して種々の未知遺伝子が発現し、微生物は増殖、 分裂および分化しているものと思われる。そこで 深海環境に生育する微生物について加藤博士と丸 山博士に、また超好熱菌について今中博士に話題 を提供願うことにした。また最近、海洋中に普遍 的に存在する特定のタンパク質が発見され、実は それが細菌のポーリンであることが明らかにされ た。これについて鈴木博士に御講演いただく。一 方、湖沼が冨栄養化することにより発生するアオ コが産生するミクロシスチンは肝毒性を示し、ま た発がんプロモーション活性をもつことが明らか となった。これらについて藤木博士と白井博士に お話しいただく。
深海高水圧環境における

微生物遺伝子の発現応答

加藤千明

海洋科学技術センター、深海環境プログラム

私共の天体、地球の生物圈を考えた場合、地 表の面積の $70 \%$ 以上を占める海洋の存在抜き には語れない。そして、その海洋中の $90 \%$ 以 上の体積を占有する、深度 $1000 \mathrm{~m}$ を超える 深海域は、地球上のメジャーな部分を占める極 めて重要な生物圏であることが、古くから指摘 されている。だが、これまでは、そうした深海 域を調査するためには、高水圧という大きな壁 を乗り越えねばならず、地上や、浅海域におけ る研究と比較して、容易に科学のメスを入れる ことは困難であった。しかしながら、近年の潜 水調查機器や、高水圧に耐える深海潜水調査船 の開発と相まって、世界中の研究者の努力の甲 斐もあり、しだいにその神秘のベールが剥がさ れつつあるというのが現状である。

我々は、これまで、有人潜水調査船「しんか

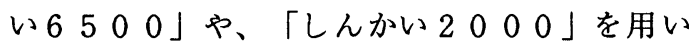
て得られたサンプルから、深海域に適応した微 生物を数多く分離してきた ${ }^{1)}$ 。そしてそうした 微生物が持つ遺伝子発現の仕組みが、高水圧に 応答して働くことを明らかとしてきた ${ }^{2)}$ 。今回 は、そうした研究の流れを概観し、大気圧下に 適応した微生物、大腸菌と比較した結果につい て報告する。我々の結果は、地球上における微 生物の進化の歴史が、本来持っていたと思われ る加圧応答する仕組みから、圧力に対して感受 性を示す仕組みへの方向に向かって、流れてき ていることを示唆しており、生命の起源は、深 海底の熱水域（熱水鉱床、ブラックスモーカー） で始まったとされる、近年の学説を支持するも のであった。

${ }^{1)}$ Kato, C., Inoue, A. and Horikoshi, K. (1996) Trends Biotechnol., 14, 6-12.

${ }^{2)}$ Bartlett, D.H., Kato, C. and Horikoshi, K. (1995) Res. Microbiol., 146, 697-706. 


\section{S - III - 2}

深海域での微生物生態

丸山明彦・工技院生命研
S - III - 3
海洋環境は地球表層の約 $2 / 3$ を占める広大な生 物圏を構成しており, 光の届かない深海域にも多 くの微生物が棲息している。ここでは, 最近注目 を集める海底熱水活動域での微生物生態と一般深 海域に遍在する低温性海洋細菌の生理・生態につ いて, 演者らの最新の研究結果を紹介する。

現地球上最高速のプレート拡大軸である東太平 洋海嶺南部 (S-EPR) 海底熱水活動域において調査 を実施した結果, この海域の微生物増殖がマグマ 爆発初期の噴出熱水成分中イオウやメタンの供給 と密接に関係していること, 爆発後の熱水噴出物 の巨大な広がり（熱水プルーム）にのって微生物 が深海域に拡大していること等が明確になった。 また本海域での微生物一次生産規模の調查から, 全海洋における化学合成一次生産(CNPP)規模を 概算し, 海洋表層の光合成一次生産(PNPP)の 0.1 〜 1\%に相当することをはじめて明確にした。一 般に表層から深層へ分解を免れて供給される有機 物量はPNPPの数\%であることから, CNPPによ る有機物の新生産は一般深海域の微生物活動に多 大な影響を及ぼしていると考えられる。また, 噴 出直後の高温熱水中から多数の微生物様粒子を検 出し, 新規の超好熱性微生物の存在を示唆した。

一般の深海域に遍在する $4^{\circ} \mathrm{C} て ゙$ 培養可能な低温 細菌は熱水活動域では見出されない。また深海由 来の低温細菌株は表層株に比べ群集レベルで低温 適応性に優れているとともに, 16SrDNA分子系統 解析により表層株はHalomonadaceae科細菌, 深海 株はこれまで未報告のMoraxellaceae科細菌で占め られていることが明確となった。後者の近縁種は 南極土壌からも分離されている。本 Moraxellaceae 菌群は低温環境で高い生残性を示すことから, 低 温保存中の食品等にも常在する可能性が高い。
鈴木 聡

(高知大・農)

海洋細菌のポーリン

一海水中溶存タンパク質の起源一
海洋で生産される有機物はMicrobial loopの輪 にとりこまれ、Food webへと引き継がれて行 く。この過程で、有機物は粒子状と溶存態の形態 をとる。海洋の有機物の $99 \%$ 以上は非生物態であ り、これは海洋生態系の多様性に最も密接に関係 した有機物の形態である。

最近特定の分子量のタンパク質が海洋に普遍的 に存在することがわかった。その一つ48kDa溶存 態タンパク質 (48-DP) はN-末端アミノ酸配列 がPseudomonas aeruginosaのポーリンOprPと 極めて高い相同性を示した。PS. aeruginosaの海 洋での生息は確認されていないが同属は海洋細菌 の主要グループの一つであり、未知の菌種も多 い。したがって、48-DPはPS. aeruginosaに遺伝 的に極めて近い菌種のポーリンと考えるのが妥当 であろう。48-DPのN-末端14mer、および海洋 細菌Listonella (Vibrio) anguillarumのポーリン Omp35Laに対する抗体（それぞれ $\alpha-48 \mathrm{DP}-$ N14、 $\alpha$-Omp35La）を作成し、ウェスタンブ ロットで溶存態タンパク質の起源を調ベた。北部 太平洋・悪熱帯・南極海の試料で、 $\alpha-48 \mathrm{DP}-$ N14は主に48kDaタンパク質を、 $\alpha-O$ mp35Laは 主に35kDa付近のタンパク質を検出した。この結 果から、48-DPは海域・深度をとわず同一タンパ ク質であり、それはOprPホモログである可能性 が高まった。また、Vibrio属のポーリンも溶存態 タンパク質の起源であることが示唆された。日本 近海で $\alpha-48 \mathrm{DP}-\mathrm{N} 14$ に応する細菌の存在を調 ベたところ、抗体反応陽性の細菌が観察された。 この事実は海洋細菌の中にOprPのN-末端と共通 の抗原性を有する種が存在することを示唆してい る。ポーリンが分解系から逃れて蓄積される機構 に興味が持たれる。 


\section{S - III - 4}

超好熱菌と嫌気的石油分解・合成細菌

今中忠行・京大 院 工

\section{S - III - 5}

アオコ毒素の発がんプロモーション活性

藤木 博太 埼玉県立がんセンター研究所

\section{A ）超好熱菌}

我々は、鹿児島県小宝島の熱海水噴出口から 超好熱菌の 1 種を分離した。本菌（KOD1株）は 直径約 $1 \mu \mathrm{m}$ の不定球菌で、厚い膜に覆われて おり、極鞭毛を有していた。また、絶対嫌気性 で培養には硫黄を必要としており、その生育温

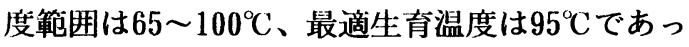
た。さらに、エーテル型の膜脂質、および細胞 壁には糖タンパク質が含まれていることや、D N A G G C 含量が $38 \%$ あることなどから、本 菌は Pyrococcus に属していることが判明した。

本菌の染色体地図 (203b kb) を作成し、多 数の遺伝子解析を行った。ここでは各種タンパ ク質 (D N A ポリメラーゼ、シャペロニン、 R e c タンパクなど）の生化学的諸特性につい て発表する。

B ）嫌気的石油分解・合成細菌

我々は油田から石油代謝に関すると思われる 細菌群を以下の様にして分離した。まず無機塩 よりなる基本培地に対して10\% 程度の $\mathrm{n}$-テト ラデカンを加え、混合ガス $\left(\mathrm{CO}_{2}: \mathrm{H}_{2}: \mathrm{N}_{2}=5: 5: 90\right)$ を通気して 37 そで 2週間培養を続けた。その 結果、この環境において生育する細菌が一株分 離され、HD-1株と名付けた。本HD-1株は嫌気条 件下でも脂肪族炭化水素および芳香族炭化水素 を資化するだけでなく、 $\mathrm{H}_{2}$ ガスを還元力、 $\mathrm{CO}_{2}$ ガスを唯一の炭素源として利用し、アルカン， アルケンを合成していることが確認できた。

すなわち環境浄化、 $\mathrm{C0}_{2}$ の固定化之再資源化 の有効例となり炭素物質循環に新しい視点を導 入するなど少なくとも一石三鳥の意味を有して いると言うことができよう。
水と共にアオコを飲用した家畜が、急性の肝 障害を起こすことは一般によく知られていた。 その原因はアオコ(藍藻)に含まれる7個のアミ ノ酸からなる環状ペプチドのミクロチスチンで あり、生じた肝障害の組織像を見た時に、ミク ロチスチンは肝発がんプロモーターとして作用 すると考えたのが、私共の研究の発端である。

ミクロチスチンはそのアミノ酸の違いにより、 40種類程報告されているが、ミクロチスチン $-L R 、-R R 、-Y R$ 等がよく実験に用いられている。 5個の環状ペプチドの、ノジュラリンやモツポ リンも藍藻から分離されており、これらは海洋 天然物研究の成果である。

ミクロチスチンやノジュラリンは一見オカダ 酸と構造は異なるが、プロテインホスファター ゼ1と $2 \mathrm{~A}$ の活性を強力に阻害した。細胞内で、 プロテインホスファターゼが阻害されると、プ ロテインキナーゼの活性は阻害されないので、 細胞内蛋白質のリン酸化は恒常的に六進すると いう生化学的変化が生じる。その結果、細胞の 形態変化、遺伝子発現が誘導される。

ラットに肝発がん剂ジエチルニトロソアミン (DEN)を $200 \mathrm{mg} / \mathrm{kg} 、 1$ 回腹腔内に投与しイニシ エーションとする。一週後より、ミクロチスチ ン-LR或いはノジュラリンを $25 \mu \mathrm{g} / \mathrm{kg}$ 週に 2 回腹 腔内に投与すると、12週で既に肝臓に多数の結 節が認められた。DEN単独、ミクロチスチン -LR或いは、ノジュラリン単独群には結節の形 成は少ない。肝臓の結節は肝がんの早期指標と して用いられているので、アオコの毒素は肝発 がんプロモーション活性をもつことが証明され た。この成果は肝がんの発生頻度が高い地区に おいて、がん䂆防研究へと役立っている。 


\section{S - III - 6}

アオコの毒性と毒素遺伝子

○白井 誠1、中野昌康2

(茨城大 $\cdot$ 生物工学 1 、自治医大 $\cdot$ 微生物 2$)$

霞ヶ浦などの富栄養化した湖沼に発生するアオ コ（ラン藻・シアノバクテリア）には肝毒素ミク ロシスチンを生産する株があり、毒素生産菌とし てはMicrocystis 株が最もよく知られている。ミク ロシスチンはD型のアミノ酸を含む環状へプタペ プチドで、毒素を腹腔投与されたマウスは出血性 のショックと肝機能不全で 3 時間以内に死亡す る。さらにミクロシスチンはプロテインフォス ファターゼ活性を阻害し、発がんプロモーターと しても働く。諸外国では飲料水源に発生する有毒 アオコが重大な環境問題となっている。演者らは 霞ヶ浦に発生したアオコの毒性に関して研究を進 めている。これまでに採取したアオコのほとんど からミクロシスチンが検出され、またミクロシス チンにはIL-6 誘導活性があることを報告した。わ が国の多くの湖沼で毒性アオコの発生が報告され ており、有毒アオコの発生はわが国でも深刻な問 題と考えられる。

現在ミクロシスチンの人の健康への影響が懸念 されており、豪州、ニュージランド、米国などで は飲料水中の基準値設定が急がれている。そのた め高感度な分析法の開発が必要となっている。し かしこれまでに構成アミノ酸が異なる約 50 種の ミクロシスチンが報告されており、その検出は容 易ではない。さらにMicrocystis 属以外のラン藻か らもミクロシスチンあるいは類似の構造と作用を 持つ毒素の検出が報告されている。そこで毒性株 の検出あるいはその防除のために毒素合成遺伝子 のクローニングが試みられている。本発表ではミ クロシスチンの毒性を概観し、演者らが取り組ん でいるモノクロナール抗体による毒素検出および 八エを用いた毒性検出と毒素遺伝子のクローニン グについて述べる。
S - IV

細菌感染と宿主応答

司会：内山竹彦 (東京女子医大・微生物免疫) 石川博通（慶応大・微生物）

病原微生物が侵入すれば、生体はこれらに 対して様々な反応を示す。多くの場合は、宿 主は感染症から回復し健康状態を取り戻す。 この時は生体は多様かつ精緻な生体防御機構 がうまく働き、病原微生物の排除に成功した のである。不幸な場合には、宿主側の抵抗因 子が作動せずに微生物が一方的に宿主を攻撃 して勝利をおさめたと解釈される症例に遭遇 する。今日の研究は、このような症例でもも 生体は侵入微生物ないしはその産物に積極的 に応答しその結果不幸な転帰をとることが多 いことを示している。感染症が慢性の経過を とる時は、病原微生物と生体の抵抗因子や標 的細胞の間に長期にわたる応答が続いてい る。それ故に感染症の全体的な理解には生体 側の多様な応答機構を理解することが必須で ある。

生体の生体防御機構は複雑であり、容易に その全体を捕らえることはできそうもない。 しかしわれわれは常にその努力を続けていか ねばならない。本シンポジウムではエンドト キシンやスーパー抗原性外毒素による生体防 御機構の活性化機序 (これが異常反応につな がる)、サイトカインの誘導、生体に備わる非 特異的防御機構、病原因子の侵入の機会が最 も大きな腸管における生体防御機構、さらに は最近注目される $\mathrm{CD} 4^{+} \mathrm{NK} 1^{+} \mathrm{T}$ 細胞の役割 等について時間の許す限り討論したい。本シ ンポジウムが感染症理解の一歩となればと希 望します。 


\section{S - IV - 1}

後天性免疫不全症候群マウスにおける スーパー抗原ショックおよびエンドトキシンショ ックの病態

O吉開泰信 ${ }^{1}$ 、青木克益 ${ }^{1}$ 、広松賢治 ${ }^{1} 、$ 西村仁志 ${ }^{1} 、$ 石田博 ${ }^{2}$ 、牧野正彦 ${ }^{3}$ 、江本正志 ${ }^{4}$ ('名大·医·病態

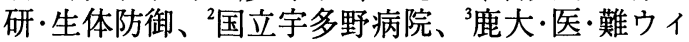
ルス研、 ${ }^{4}$ 北里大·理·生体防御）

LP-BM5マウス白血病ウィルスの感染によって 発症するマウス後天性免疫不全症候群 (murine acquired immunodeficiency syndrome:MAIDS）はリン パ球の異常増殖が見られる以外、 $\mathrm{T} 、 \mathrm{~B} リ ン ハ ゚$ 球 の機能不全やサイトカイン産生異常など、ヒトA I D S と共通する病態を示す。今回、MA I D S マウスの細菌重複感染症における病態形成機序を エンドトキシンまたは細菌性スーパー抗原性ショ ックおよびListeria monocytogenesまたは

Mycobacterium avium複合感染症モデルで検討した。 MA I D S マウスではエンドトキシンショック に対する感受性が立進していた。L P S 投与後の 血中 T NF $\alpha$ 産生にはコントロール群との間に差 が認められなかったが、MA I D S マウスでは I $\mathrm{F} \mathrm{N}-\gamma 、 \mathrm{I} \mathrm{L}-1 \beta$ 産生の著明な充進が見られ た。G-G S F 投与はこれらサイトカイン産生を 抑制し、MA I D S マウスのエンドトキシンショ ックを防御した。

一方、細菌性スーパー抗原であるブドウ球菌エ ンテロトキシンA（staphylococcal enterotoxin A:SEA）によるショックに対する感受性はMA I D S マウスで低下していた。MAＩＤＳマウスで はSEA反応性 T 細胞の増殖は正常であり、SEA投 与後の I L - 2 産生は増強していた。しかし同時 に過剩な I L - 10 の産生も認女られ、抗 I L 10 抗体投与によってMA I D S マウスのS E A ショックの感受性が増加した。このことより、過 剩な I Lー10の産生がMA I D Sにおける細菌 性スーパー抗原性ショックの防御に㗢いていると 考えられる。

MA I D S マウスではL.monocytogenes感染症に 対して正常群と同等の抵抗性を示した。一方、 $M$. avium 感染症に対して抵抗性が減弱していた。感 染MA I D S マウスでは I F Nー $\gamma$ と I L-10 を産生するTh0様抗原特異的 T 細胞が産生されて おり、このタイプの T細胞はListeria感染防御には 働くが、Mycobacteria感染防御には充分ではないと 考えられる。

\section{S - IV - 2}

細菌性スーパー抗原によるT細胞トレランス誘導 機序の解析

\section{八木淳二、内山竹彦}

\section{東京女子医大・微生物免疫}

1980年代後半から、微生物は一連のユニーク な蛋白を産生することがわかってきた。それら は、細菌の外毒素として知られていた蛋白やマ ウス乳癌ウイルスの産物などであり、一括して スーパー抗原と呼ばれている。スーパー抗原は、 ペプチド化されることなく、直接MHCクラス II 分子に結合するとともに、T細胞抗原レセプター $\beta$ 鎖のV領域 $(\mathrm{V} \beta)$ の外側部に結合してT細胞 を活性化してしまう。したがって、特定のV $\beta$ 遺伝子断片の産物を表現する莫大な数のT細胞集 団が反応細胞となる。

ある種の感染症では、スーパー抗原が大きな 関与をしていることがわかってきた。毒素性シ ヨック症候群における毒素性ショック症候群ト キシンー 1 やブドウ球菌腸管毒素、また、われ われがYersinia pseudotuberculosis感染患者か ら分離、精製することに成功したYersinia pseudotuberculosis由来の新しいスーパー抗原 (YPM）がその例として上げられる。これらは T細胞の異常に強い活性化を導いて、産生された 大量のサイトカインが生体異常反応を引き起こ すと考えられている。われわれは、細菌性スー パー抗原に対する宿主の免疫応答を検討するこ とにより、細菌感染の制御に結び付けたいと考 えている。

マウスに細菌性スーパー抗原を投与すると、 多彩な免疫応答が惹起される。特定のV $\beta$ 陽性 $\mathrm{T}$ 細胞は、活性化に引き続いてアポトーシスによ りクローン消失するか、スーパー抗原特異的な アナジーに陷る。われわれは、最近、このよう なトレランス誘導にIL-2の枯渴が強く関わって いることを明らかにした。本シンポジウムでは その知見をもとに、トレランス誘導機序を中心 に、細菌性スーパー抗原に対する宿主の免疫応 答について考察したい。 


\section{S - IV - 3}

下気道における細菌感染とIL-8誘導

大石和徳

(長崎大学・熱研内科)

\section{S - IV - 4}

細菌内毒素によるアポトーシスの誘導

横地高志 愛知医大微生物免疫
細菌性の肺炎を含む下気道感染症においては種々 の程度の好中球浸潤とともにTNF $\alpha$, IL-1 $\beta$, IL-8などの炎 症性サイトカイン産生が認められる。これらの炎症性サイト カイン産生は、一部にはグラム陰性菌のLPSが肺胞マク ロファージを刺激することにより誘導されると考えられる。 しかしながら、気道感染症の病態においては肺胞マクロ ファージ(AM)の関与はむしろ少なく、気道上皮が局所に おける炎症過程に中心的な役割をすることが考えられる。 そこで、我々は細菌感染による気道上皮細胞 (BET-1A cell)が、LPS以外の複数の細菌性因子により刺激され IL-8を誘導することを見いだした。特に、呼吸器感染症 の重要な起炎菌である緑膿菌の菌体破砕上清(SSPA) 中から強力なIL-8 誘導活性を有する分子量 $59 \mathrm{kDa}$ の耐 熱性蛋白を精製した。この精製蛋白はそのN-末端アミノ 酸配列の解析から、Pseudomonas nitrite reductase (PNR)なる緑膿菌の periplasmic spaceに存在する酵素 であることが判明した。この酵素は好気性条件では cytochrome oxydase活性、嫌気性条件では nitrite reductase活性を有している。しかしながら、SSPAは好気 性条件では還元型Pseudomonas cytochrome c-551を 酸化する活性を有するのに対し、精製したPNRはこの活 性を有してなかった。このことから、PNRのIL-8誘導活性 はその酵素活性とは関連しないと考えられた。また、こ のPNRは気道上皮において1hで最大のIL-8mRNA発現 を誘導し、他の蛋白合成は必要としないことから直接結 合がその作用機序と推察された。さらに、PNRは肺胞上 皮細胞、肺線維芽細胞、好中球、 $\mathrm{AM}$ に対しても同様に IL-8産生を誘導した。とくに、AMにおいてはIL-8のみなら ずTNF $\alpha, \mathrm{IL} 1 \beta$ をも誘導した。以上の結果から、緑膿 菌 性下気道感染症患者において菌体より放出されたPNR は気道における持続的な好中球浸潤に重要な役割を 果すことが示唆される。また、緑膿菌以外の呼吸器病原 性菌の菌体破砕上清中にも気道上皮における同様の IL-8誘導活性を認めることから、緑膿菌以外の病原性 菌においても気道上皮におけるIL-8誘導因子が存在す ることが推定される。(共同研究者:長大熱研内科;サー・ ボラン、苑田文成、永武毅、同細菌; 平山壽哉、和田昭 裕、阪大蛋白研; 日高雄二、東大医学部;松島綱治）
細菌内毒素は、エンドトキシンショックやDIC を引き起こし、細胞傷害や臓器障害を伴った 多臓器不全へと発展する。この際、急性肝壊 死とか急性尿細管壊死と呼ばれる大量な細胞 死が誘導される。近年、細胞死はアポトーシ スとネクローシスとに区別され、その機序も しだいに明らかとなってきた。我々は、エン ドトキシンによって引き起こされる各種細胞 群の死がアポトーシスによって引き起こされ、 そのアポトーシスをおこす標的細胞は、エン ドトキシンの投与方法によって著しく影響さ れることを報告してきた。たとえば、正常な マウスにエンドトキシンを投与すると、免疫 系葴器のみに選択的にアポトーシスが誘導さ れる。すなわち、胸腺皮質細胞、 $\mathrm{CD} 5+\mathrm{B}$ 細胞、 germinal center B記憶細胞などである。また、 D-ガラクトサミンと共にエンドトキシンを投 与し、実験的エンドトキシンショックを誘導 すると、肝細胞と腎乳頭部細胞にアポトーシ スが誘導される。全身性シュワルッマン反応 を用いた実験的DICでは、血管内皮細胞、尿細 管細胞にのみアポトーシスが認められる。各 実験系でのアポトーシス誘導機序はそれぞれ 異なった作用分子、すなわちサイトカイン、 グルココルチコイド、接着分子、一酸化窒素 (NO) などが複雑に関与しており、そのメカニ ズムも多彩である。エンドトキシンによって 誘導される実験的なアポトーシスの全体像を 明らかにすると共に、エンドトキシンの臨床 的な病態におけるアポトーシスの関与につい て報告したい。 


\section{S - IV - 5}

殺菌物質デフェンシンの作用機序

小橋 修

佐賀医科大学微生物学教室

好中球の殺菌機構には活性酸素系、NO系の 酸素依存性殺菌系と酸素非依存性殺菌系があ り、NO系を欠損した miceでも殺菌機構が残っ ている。酸素非依存性殺菌系の中でも特に重 要な殺菌物質としてのデフェンシンについて 述べる。末梢白血球を超音波処理後、酸抽出 し、デフェンシン粗分画を得、細菌に対する 殺菌活性を調べ、さらに acid urea PAGEにて $3 \sim 4$ 種のデフェンシン分画とHPLCにて精 製デフェンシンを得た。一方合成されたデフェ ンシン数種の殺菌活性を調べた。デフェンシ ンの構造と殺菌機構：デフェンシンは29～34 個のアミノ酸からなり、3つの S-S 結合を作 る 6 個のシステイン残基を持つ塩基性ペプチ ドである。大部分のイオンチャンネル形成蛋 白は $\alpha$ helix構造を有しているが、デフェンシ ンは $\beta$ sheetのみで構成され、ダイマー又はポ リマーを形成して殺菌活性を示すとされてい る。 def 遺伝子の発現様式：ヒト白血病細胞 株 HL-60 や患者由来の白血病細胞を用いて デフェンシンの生合成またはデフェンシンの mRNA 転写活性が調べられ、前骨髄細胞まで は、まず def 遺伝子の転写が起こり白血病細 胞内に蓄積され、一部は細胞外に分泌される。

一方、成熟白血球の顆粒中には成熟デフェン シンが蓄えられている。殺菌作用：グラム陽 性菌もグラム陰性菌も約 20 分かけて殺菌さ れる。一方、黄色ブドウ球菌のある株はデフェ ンシンと接触した瞬時に破壊される。電顕像 では、メソゾームが多数出現していたが、メ ソゾーム出現と殺菌機構との関連は不明であ る。一方、デフェンシンに対する耐性菌は作 成できなかったが殺菌機序を考えるうえで興 味ある知見を得たので合わせて報告する。
S - IV - 6

\author{
腸管粘膜の免疫応答 \\ -IELの発達分化と生理的機能について一 \\ 南野昌信（ヤクルト中央研、免疫） \\ 石川博通（慶応大·医·微生物）
}

腸管腔には常在細菌を初めとする無数の微生 物が棲息し、腸管粘膜は常に感染の危険に曝さ れている。小腸のパイエル板、粘膜固有層、上 皮細胞間には多数のマクロファージやリンパ球 などの免疫担当細胞が分布し、全体として腸管 付属リンパ組織を構築する。近年特に小腸上皮 細胞間 T細胞(IEL)の発達分化機構や生理的機能 の解明が望まれている。IELはTCR $\alpha \beta^{+} \mathrm{T}$ 細胞 $(\alpha \beta-$ IEL) と TCR $\gamma \delta^{+} \mathrm{T}$ 細胞 $(\gamma \delta$-IEL)から構成され、それ ぞれが更に多数のサブセットに分けられる。無 菌マウスやMHC class I抗原発現阻止マウス( $\beta 2$ ミクログロブリン欠損マウスおよびTAP1欠損マ ウス)の解析から、 $\alpha \beta-I E L の$ 発達分化が腸内細菌 定着やMHC class I抗原発現によって促進される のに対し $\gamma \delta$-IELの発達分化は腸内細菌やMHC class I抗原とは無関係であることが明らかとなっ た。一方、遺伝的にパイエル板やリンパ節を欠 損するalyミュータントマウスの解析から、いず れのIELもパイエル板を経由せずに発達分化でき ることが明らかとなった。さらにIL-7 $\mathrm{R}^{-/}$-マウス の検索結果より、IL-7/IL-7RシグナルがIELの発 達分化に重要であることが示された。IELの生理

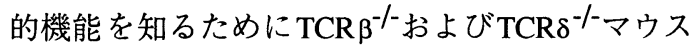
の腸管上皮細胞を検索した結果、 $\gamma \delta$-IEL欠損は 小腸上皮細胞の増殖速度や MHC class II抗原発現 の低下を引き起こすことが観察された。また、

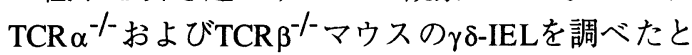
ころ、 TCR $\beta^{-/-}$- $\gamma \delta$-IELの細胞傷害活性がTCR $\alpha^{-/-}$ に比べて著しく減弱することが確かめられた。 これらの新知見は $\alpha \beta$-IELと $\gamma \delta$-IELが異なった経 路で発達分化し、それぞれが特有の生理的機能 を担うことを提示している。 


\section{S - V}

遺伝子異常と易感染性 : 遺伝子欠損マ ウスを用いた解析

高津聖志（東大・医科研・免疫）

菅村和夫（東北大・医・細菌）

病原微生物の侵入に際し宿主は抗原に特異的 あるいは非特異的な免疫系を機能させ、感染防 御が成立する。これら免疫系には種々のエフェ クター細胞が関わっているが、それらの発生・ 分化・増殖ならびに機能発現の制御機構が分子 レベルで明らかになるにつれ、それらの制御機 構に関わる機能分子の遺伝子変異が免度不全を 惹起し、易感染性の原因となることが知られて いる。宿主の感染制御に関与する細胞群や免疫 機能分子が明らかになり、個体レベルでの研究 が注目されるようになってきた。

リンパ球の活性化や機能発現には細胞表面の 機能分子、細胞内シグナル伝達分子、転写因子 などの共役が必須である。すでに、免疫系を制 御する種々の機能分子の遺伝子欠損マウスも作 出され、易感染性モデ動物実験系として解析 されている。そこで、本シンポジウムでは免疫 異常と易感染性について、我が国で開発された 代表的な遺伝子久損マウスについて話題を提供 して頂き、多角的に捉えた感染防御機構の討論 を期待する。

今回のシンポジウムにおける発表内容、なら びに討論テーマとしては、細菌感染に梁く関与 するマクロファージのスカベンジャー受容体、 T細胞やB細胞の活性化に必須のCD40/CD40リガ ンド系やサイトカイン/サイトカイン受容体系、 サイトカインシグナル伝達に関与する転写因子 に絞り、それらの感染制御における役割を考え、 その異常と易感染性について議論したい。
S - V - 1

スカベンジャー受容体の細菌感染における役割

切替照雄 ${ }^{1 、}$ 中野昌康 ${ }^{1}$ 、肾玉龍彦 2

(自治医大 $\cdot$ 微生物 1 、東大 $\cdot$ 先端研 2$)$

マクロファージ（M $\phi)$ は、宿主に侵入してき た細菌を初期に認識する免疫細胞である。従っ て、M $\phi$ 上で細菌が結合する受容体の遺伝子を 欠損したマウスを用いた解析は、細菌感染の成 立の機構や感染病態の解明のための有力な手段 となると考えられる。スカベンジャ一受容体は $\mathrm{M} \phi$ がアセチル化などの化学修飾を受けた低密 度リポタンパク質（LDL）などをエンドサイ トーシスし、処理するための受容体である。こ の受容体はグラム陰性細菌の菌体表層成分であ るLPSのM $\phi$ 上の受容体の一つでもあることが最 近明らかにされている。しかし、LPS受容体と

してのスカベンジャー受容体の機能や役割につ いては全く知られていない。児玉らはスカベン ジャー受容体遺伝子をクローニングし、その遺 伝子欠損マウスの作製に成功した。本研究では、 スカベンジャ一受容体遺伝子久損マウス $\mathrm{M} \phi$ の LPS刺激にもとずくサイトカインや一酸化窒素

（NO）の産生性さらにこのマウスのサルモネラ やリステリア感染に対する感受性を解析した。 これまでの解析では、スカベンジャー受容体欠 損マウスと正常同腹マウスとを比較すると大き な違いは観察されず、むしろバックグラウンド 遺伝子の不均一性のほうがより大きく影響する 場合もあった。デキストラン硫酸や酸化LDLは スカベンジャー受容体のリガンドの一つである が、M $\phi$ をこらで処理すると、LPSによるNO 産生が著しくて低下することが最近報告されて いる。しかし、これらのリガンドは、スカベン ジャー受容体欠損マウスM $\phi$ の LPSによるNO産 生をも同程度に抑制した。以上スカベンジャー 受容体欠損マウスを用いた解析から、M $\phi$ には スカベンジャー受容体以外のスカベンジャー経 路が存在することが示唆された。 


\section{$\mathrm{S}-\mathrm{V}-2$}

感染免疫とCD40-CD40L相互作用

菊谷仁（阪大・微研）

CD40を介したシグナルは、B細胞の増殖分化 において重要な役割を果たしており、CD40や CD40Lを欠損したマウスではT細胞依存性の class switchや胚中心(GC)形成が欠失しているこ とから、CD40-CD40L相互作用が体液性免疫の 成立に必須であることが証明されている。更 に、T細胞の活性化においても CD40-CD40L相 互作用が重要であり、ある種の細菌感染に対 する細胞性免疫に必須の役割を果たしている ことが明らかになってきた。例えば、 Leishmania majorの感染に対する免疫反応はTh1 細胞の出現に大きく依存し、L. majorに対し感 受性のBALB/cマウスにおいてはTh1反応が成立 せず逆にTh2反応が出現してくることが知られ ている。CD40(-/-)マウスはL.major感染に対し て非常に感受性であり、BALB/c以上に極性の 強いTh2反応を示す。このCD40(-/)マウスのL. majorに対する感受性及びTh2反応の出現は、 CD40依存性のIL-12産生が全く欠失しているた めであることが明かになっている。更に、試 験管内において、正常 macrophage 上のCD40を 刺激することによりLeishmania傷害性を誘導す ることが出来る。これらの結果は、CD40は L.majorに対する細胞性免疫の二つの異なる相、 即ち Th1/Th2細胞分化の決定と macrophageへの 細菌傷害性誘導において機能していることを 示している。一方、マウス乳腺腫ウイルス (MMTV)などの一部のレトロウイルスが感染す る際に、宿主の免疫反応を利用していること が知られている。CD40欠損マウスの解析から、 MMTVの感染成立にはCD40、CD40L相互作用 が必須の役割を果たしていることも明らかに なっている。

\section{S - V- 3}

サイトカイン共通受容体 $\gamma$ 鎖

の変異による免疫不全マウス

菅村和夫

東北大医細菌

インターロイキン 2 (IL-2)受容体 $\gamma$ 鎖は、IL-2、 IL-4、IL-7、IL-9、IL-15の各受容体の共通サブユ ニット（ $\gamma \mathrm{c}$ 鎖）であり、ヒトでは $\gamma \mathrm{c}$ 鎖変異に よってX連鎖重症複合免疫不全症 (XSCID) が 発症する。XSCIDはT 細胞およびNK細胞の初期 分化增殖障害と B 前駆細胞分化増殖障害を伴う。 特に、T細胞およびNK細胞の初期分化増殖障害 にはIL-7が必須な役割を担っていることが、す でにIL-7遺伝子久損マウスからも示唆されてい る。他方、 $\gamma$ c鎖に会合するJak3チロシンキナー ゼ遺伝子の変異もまたXSCIDと同様な免疫不全 症の原因になっていることが分かっている。こ のように、 $\gamma \mathrm{c}$ 鎖を介するシグナル伝達が $\mathrm{T}$, NK細胞の発生に必須に関わっている。

我々は $\gamma \mathrm{c}$ 鎖機能不全に起因するXSCIDのモデ ル動物を作出する目的で、 $\gamma \mathrm{c}$ 鎖遺伝子变異マウ スを作出した。 $\gamma \mathrm{c}$ 鎖変異マウスでは、胸腺の萎 縮と共に、成熟 $\mathrm{T}$ 細胞が著名に減少し、同時に $\mathrm{NK}$ 細胞も全く検出されなかった。また、成熟 $B$ 細胞も著名に減少し、B細胞分化はプロ $\mathrm{B}$ 細胞 までで、それ以降が阻害されていた。このよう に、 $\gamma \mathrm{c}$ 鎖変異マウスは $\mathrm{T}, \mathrm{B}, \mathrm{NK}$ 細胞が共に 障害された免疫不全マウスである。興味深いこ とに、 $\gamma \mathrm{c}$ 鎖変異マウスでは脾蔵が肥大し、そこ には血液幹細胞が多数存在し、䯣外造血の六進 が示唆された。他方、IL-2遺伝子久損マウスと 同様に、 $\gamma \mathrm{c}$ 鎖変異マウスにおいても

Inflammatory Bowel Disease様の症状か観察された。 これらの症状がどのような機構によってもたら されているのかについて考察する。 


\section{S-V- 4}

IL-5レセプター欠損マウスと易感染性

高津聖志、吉田年美、吉村堅太郎 2 、高木 智 （東大・医科研・免疫、2 秋田大・医）

インターロイキン5（IL-5）は自然抗体の産 生、活性化B細胞のIgA産生細胞への分化、好酸 球の産生に必須のサイトカインである。IL-5レ セプター（IL-5R）はIL-5特異的な $\alpha$ 鎖と、シグ ナル伝達分子である $\beta$ 鎖から構成される。IL5/L-5R系の易感染性における役割を解析するた め、IL-5R $\alpha$ 鎖遺伝子欠損マウスを作製した。变 異マウスは飼育環境下で健康であり、脾臓や骨 䯣の細胞数や B 細胞、 $\mathrm{T}$ 細胞の発生に異常は認 められなかった。興味深いことに腹腔内のB-1 細胞の減少、血清中のIgM、IgG3の低下、末梢 血中の好酸球の割合の減少が見られた。変異、 ウスのB細胞はIL-5に全く応答せず、IL-5により 誘導される好酸球産生も全く認められなかった。 これらのことより、IL-5はB-1細胞、好酸球の 分化及び自然抗体の産生を制御していることが わかる。IL-5R $\alpha$ 鎖欠損マウスに広東住血線虫 をさせたところ、通常野生型マウスで見られる 涟液中の好酸球增多は認められず、野生型に比 べて脳内虫体数の増加および虫体の長さの増加 が見られた。この結果は、IL-5によって誘導さ れる好酸球がある種の寄生虫感染に強力なエフ エクター細胞として機能していることを示唆し ている。IL-5のシグナル伝達に関しても話題を 提供したい。

\section{S-V-5}

IRFファミリー転写因子群による 生体防御

○澈 伸介、谷口紹維

（東大·医 $\cdot$ 免疫）

病原体感染に対する免疫応答においては、へ ルパーT細胞（TH）サブセット、即ち TH1と TH2が感染源に応じて適切に分化することが重 要である。我々はこのプロセスを遺伝子発現調 節機構の観点から明らかにすることを目的とし て、インターフェロン制御因子（IRF）-1の役割 を検討している。IRF-1は当初インターフェロン

（IFN）- - 遺伝子の転写活性化因子として同定さ れたが、その後の研究によって、細胞增殖やア ポトーシスに関連する遺伝子群（ICE、p21）の 転写制御因子でもあることが明らかとなり、現 在では様々な細胞外からの刺激に対する細胞応 答に際しての遺伝子発現制御に必須な因子と考 えられている。感染防御の観点から興味梁いの は、IFNの抗ウイルス作用を担うIFN誘導遺伝子 群のみならず、IFN- $\gamma$ で誘導される誘導型一酸化 窒素合成醉素（iNOS）遺伝子の発現がまた、こ の転写因子の制御下にあることである。実際、 IRF-1を欠損するマウスはBCG感染をコントロー ルできない。本シンポジウムでは、我々がこの 欠損マウスを用いて明らかにしたIRF-1遺伝子欠 損のTHサブセット分化への影響について述べた い。この欠損マウスではTH1の分化に障害があ り、相対的にTH 2 が優位になっている。IRF-1久 損の影響はT細胞および抗原提示細胞に及んでい るが、加えてこのマウスでは、感染初期におい てTHサブセット分化に重要な役割を果たすと言 われているNK細胞が久損しており、IRF-1が感 染防御システムの複数の局面で決定的な役割を 果たしていることが分かる。従って、いかなる 遺伝子群がIRF-1の転写制御下にあるのかを知る ことで生体防御機構の理解とその制御法の開発 に寄与できるのではないかと考えている。 


\section{S - V - 6}

サイトカイン・シグナル伝達に関わる 転写因子のノックアウト

審良静男（兵庫医大·生化学）

免疫系は、T細胞やマクロファージおよびそ の他の免疫細胞が分泌する一群のサイトカイ ンによって複雑なネットワークを形成してい る。近年各種のサイトカインの遺伝子発現調 節機構や転写調節因子の研究が進み、サイト カイン発現やシグナル伝達は少数の転写因子 ファミリーによって担われていることがあき らかとなってきている。これらには、NF-кB, NF-IL6(C/EBP), Fos-Jun, CREB/ATF, STAT, NF-ATファミリーが含まれる。特にNF-KB と NF-IL6ファミリーは、協調して多くの炎症性 サイトカンや炎症にかかわる接着分子等の誘 導に関わることが知られている。一方、STAT ファミリーメンバーは、各種サイトカインの エフェクター分子の遺伝子を支配し, その発現 誘導に関わっている。

われわれは、NF-IL6とSTATファミリーの各 転写因子の生体内での役割を調べるためにノッ クアウトマウスを作製している。このうち、 NF-IL6ノックアウトマウスは、極めて少量の リステリア菌の腹腔内感染により死亡するこ とが判明した。このマウスのマクロファージ は、取り込まれたリステリア菌を殺菌できず、 細胞質内にリステリア菌がエスケープし分裂、 増殖していた。マクロファージによる殺菌機 構に重要なNO産生に異常はみられずNO非依存 性の殺菌作用の存在があきらかとなった。ま た、STAT6ノックアウトマウスでは、IL-4シグ ナル伝達に異常がみられ、Th2反応や IgEへの クラススィチングがみられず、STAT6がIL-4の 作用発現に必須の転写因子であることが証明 された。
S - VI

薬剂の能動的排出

中江太治、山口明人

（東海大学医学部、大阪大学産業科学研）

細菌からヒトに至るすべての生物は、長 い生存の歴史の間に多くの毒物、自然界に存在 する化合物に曝されて来た。生物はこれらの有 害物質を解毒すること及び細胞外に排出する事 によって生き延びてきたものと考えられる。そ の 1 つは本シンポジュウムのテーマである細菌 による毒物及び薬物の排出作用であり、またヒ トでは癌細胞による抗ガン剂の排出の機構であ る。本シンポジュウムでは生物に普遍的に存在 すると考えられる毒物及び薬物の細胞外排出を 医学的に興味ある細菌を用いて行った研究を集 め討論しようと企画された。このような研究を 通して排出機構の抗生物質. 消毒剂耐性に杲た す役割を理解し、ひいては薬剂排出を阻害する ような化合物の開発につなげることができれば 幸いである。もしこの抗生物質排出ポンプを不 活化する様な化合物を発見することが出来るな らば、これまで開発された多くの抗生物質は一 層の抗菌効果を示し、また比較的効力の弱かっ た薬剤も改めて使用可能となり、ひいては薬物 による副作用を極度に軽減できる。このような 将来の発展を期待するために今なされなければ ならないことは、この薬剤排出ポンプの性質を 細胞膜、タンパク質及び遺伝子レベルから明ら かとすることである。 
S - VI - 1

細菌の消毒剂酎性機構

笹津備規

昭和薬大・微生物

細菌の消毒剂耐性に関しては、これまで抗生物 質酎性とは異なり，緑膿菌のように本質的に消毒 剂に対する感受性の低い菌種が存在するのだと考 えられてきた。1980年代に消毒剤を排出する遺伀 子の存在が報告され，黄色ブドウ球菌を中心に消 毒剤耐性遺伝子の研究が開始された。

黄色ブドウ球菌の消毒剂耐性については，オー ストラリアのR.A. Skurrayらのグループと演者ら のグループにより研究が進められてきた。1984年 D.E. Townsendらによって初めてメチシリン耐性 黄色ブドウ球菌（MRSA）の消毒剂酎性に関する報 告がされた。1985年には J.M. Tennent らにより 消毒剂耐性遺伝子がクローニングされ，その後 qac A, qac B, qac C ( qac D, ebr, $s m r$ ), qac C’, qac $\mathrm{E}$, qac $\mathrm{E} \Delta 1$, qac $\mathrm{F}$, EBR など 8 種類の消毒剂耐性遺伝子が報告されている。この うち $q a c \mathrm{~A}, q a c \mathrm{~B}, q a c \mathrm{C}, q a c \mathrm{C}^{\prime}, q a c \mathrm{~F}$ はブ ドウ球菌を中心としたグラム陽性菌から，qac E, qac $\mathrm{E} \Delta \mathrm{I}$, EBRはグラム陰性から分離された。 qac Aおよび qac B 遺伝子は12回膜貫通型の膜蛋 白を，その他の遺伝子は 4 回膜貫通型の膜蛋白を コードしている。酎性機構としては，全て細胞膜 からの消毒剤の排出であると報告されている。 qac C 遺伝子は伝達性プラスミド上にも存在し, 日本でも黄色ブドウ球菌を中心に広く分布してい る。 qac Eおよび qac E $\Delta 1$ 遺伝子の分布はこれ まで明らかではなかったが, 演者らの研究により K. pneumoniae 由来の qac E遺伝子は緑膈菌にも 存在し, インテグロンの保存領域に存在する $q a c$ $\mathrm{E} \Delta 1$ 遺伝子はグラム陰性菌に愊広く分布してい ることが明らかになった。このような耐性株が， 実際の消毒に対しどのように抵抗するかといった 問題も含めて報告する予定である。
S - VI - 2

\author{
バクテリアの薬剤腓出輸送活性の \\ 培養条件による変化 \\ 一 '代謝ストレス'による活性化 -
}

○加茂直樹, 宮内正二・北大薬

高度好塩菌 Haloferax volcanii からドキソルビ シン (DOX) 而性株を分離した.この株は抗腫瘍薬や 蛍光色素など構造上関連性のない様々な薬物を排出す る多剂排出輸送担体により耐性を獲得する. 排出活性 はローダミン 123 の細胞よりのefflux速度測定より 定量できた，排出輸送活性はA T P 駆動であり， C a 拮抗剤は排出を阻害した。

野生株にも弱いながらも排出活性が見られる. 高 度好塩菌は一般的に糖を利用できないが, Hf. volcanii は糖を資化でき，Naとの共輸送である，通 常の培地に高濃度のグルコース（Gc, $55 \mathrm{mM}$ )を 添加して野生株を培養すると, 排出活性が 4 ～5倍 上昇した. $4 \mathrm{M} \mathrm{NaC}$ を基本培地とするので浸透圧が 原因ではない，駆動力である細胞内ATP濃度は培地 中のGcの存在に依存しなかった Gc存在下の培養 により高い排出活性を持った菌体を，通常の培地で 培養するともとの低い活性に戻った。

非代謝性であるL-Gc, 2- deoxygl ucoseおよび3O methyl glucose の培地への添加では排出の活性は 上昇しなかった 従って, 何らかの意味で, 糖の代 謝が必要である.

同様に培地に大過剩のアミノ酸を添加しても野性 株の排出活性の増大が見られた. 18 種のアミノ酸 を調べたところ，一般的に疎水性アミノ酸添加で大 きな排出活性を野生株は獲得したが，添加アミノ酸 の疎水性のみでは説明出来なかった。

以上の事より，栄養物が大過剩に存在するときに は異常な代謝が起こり, 通常では生じない何らかの 意味で有害な物質が出来て，それを排除するために， 排出輸送体が発現するのではないかと考え，

「metabolic stress」名付けた. この有害物質の同 定および輸送体発現の分子論的考察は将来の問題で ある. 


\section{S - VI - 3}

緑膿菌の薬剂而性における多剂排出系の役割

増田修久（三共・第二生物研究所）

緑膿菌が多くの抗菌薬や消毒剂に自然耐性を示 す主たる要因として、外膜の薬剤透過性が他のグ ラム陰性菌に比べ低いことが挙げられる。しかし 緑膿菌が細胞内の薬剤濃度を低く保つためには、 外膜透過性の低さ (一次要因) だけでは不十分で あり、細胞内の薬剂を除去する何らかの機構の存 在が、自然耐性の二次要因として不可欠である。 いくつかの $\beta$-ラクタム剤の場合、この二次要因は 染色体性の $\beta$-lactamase による薬剤の加水分解で ある。一方、一部のカルバペネム剤を除く $\beta$-ラク タム凨やキノロン剤、 tetracycline などの場合は、 内膜蛋白質 MexA，MexB および外膜蛋白質 OprM の三者からなる多剂排出システムが、自然耐性の 二次要因であることが最近明らかになった。

このように $\beta$-ラクタム剂に対しては加水分解 と排出という二つの薬剂除去機構があるにも関わ らず、両者の関係については議論されていない。 そこで isogenic な $\beta$-lactamase 欠損株、OprM 欠損 株および $\beta$-lactamase-OprM 欠損株を分離し、薬剤 感受性を比較した。その結果、carbenicillin や aztreonam などに対する感受性は、 $\beta$-lactamase $の$ 有無によっては影響されず、薬剤排出系の欠損に よってのみ上昇した。他の $\beta$-ラクタム剂に対する 感受性は、 $\beta$-lactamase および薬剂排出系のどちら の有無によっても影響された。Ceftriaxone など一 部の $\beta$-ラクタム剤に対する感受性は、 $\beta$ lactamase あるいは薬剂排出系のいずれか一方を欠 損させても変化せず、両者を欠損させたときには じめて上昇した。したがって $\beta$-ラクタム剤に対す る緑膿菌の自然而性は、外膜を介する細胞内への 薬剤流入の遅さ (一次要因) と $\beta$-lactamase と薬剂 排出ポンプによる細胞内からの効果的な薬剂除去 (二次要因)によってもたらされると考えられる。

\section{S - VI - 4}

細菌の薬剤排出機構研究のモデルとしてのテト ラサイクリン排出系の研究

山口明人（阪大 · 産業科学研究所）

テトラサイクリン排出蛋白はアンチポーター タイプの代表的な薬剤排出蛋白である。私たち は、薬剤排出蛋白のモデル系として、テトラサ イクリン排出蛋白の分子構造と膜輸送機構を詳 細に解析してきた。まず、分子構造に関しては、 Cys-free 変異体をもとに任意の位置に Cys を導 入した Cys 走査変異体を多数構築し、SH 試薬 による部位特異化学修飾の反応性、および膜不 透過性 SH 試薬との拮抗を解析することにより、 正確に膜貫通構造を決定する方法を確立した。 その結果、グラム陰性細菌のテトラサイクリン 排出蛋白 $\operatorname{Tet}(\mathrm{B})$ に関しては 12 回膜貫通構造が 実験的に確定された。一方、これまで 14 回貫通 型と推定されていたグラム陽性細菌の Tet(K)に 関しては、推定とは異なる結果が得られたが、 最終的な結果はシンポジウムの場で報告したい。 次に、膜輸送機構に関与する機能残基に関して 解析した。輸送される基質がテトラサイクリン -2 価カチオンキレート体なので、膜貫通領域 の酸性残基が重要な働きをするものと推定され ていた。Tet(B)については膜貫通領域に 3 個の Asp があり、いずれも必須な残基で、とくに Asp285 はテトラサイクリンの結合に関与して いることが証明された。一方、 $\operatorname{Tet}(\mathrm{K})$ には膜貫 通領域に Asp が存在せず、3 個の Glu が Tet(B) における Asp と同様の働きをしていた。親水性 ループ領域に関しては、Tet(B)では $\mathrm{N}$ 末端側最 初のループ領域にあるAsp66が唯一の必須酸性 残基で、基質と最初に相互作用して蛋白の open/close コンホメーション変化を引き起こす 残基であったが、 $\mathrm{Tet}(\mathrm{K})$ では同様の働きをする Asp 残基が $\mathrm{C}$ 末端側のループ領域に存在してい ることがわかった。 


\section{S - VI - 5}

緑膿菌における薬剂排出と耐性

中江太治

東海大学医学部分子生命科学部門

緑膿菌の薬剂耐性は低い外膜の透過性及び抗生 物質修飾酵素の産生がその原因であるとされて きた。事実 $\beta$ ラクム剤などにおいてはこの二 つの因子が共役的に働くことによって高度耐性 となる。ところがこれでは緑膿菌が修飾酵素を 産生しないクロラムフェニコール、テトラサイ クリン、ニューキノロン剂等に対する耐性を説 明するには不充分である。我々はこのような構 造的に関連の薄い抗生物質に耐性を示す菌の性 質を調べたところ、それらはテトラサイクリ

ン、ニューキノロン剂等の細胞内蓄積量が低い ことを見出した。その後この排出に係わる蛋白 をコードする遺伝子をクローン化したところ、 これらはK. Pooleらが鉄キレーター排出蛋白と 信じてクローン化したmexA-mexB-oprMと同 一であることが分かった。これら遺伝子の一部 をプローブとしてこれまでに分離されている緑 膿菌多剂耐性菌におけるmex遺伝子の発現を調 ベたところnalB変異株ではこのメックスオペロ ンの転写が亢進していたが、nfxB及びnfxC変 異株では野生株のそれと同程度の発現であっ た。そこでMexA, MexB及びOprMの薬剤排出 に係わる役割を明らかとする目的でこれらの遺 伝子の各々を破壊した株を構築して薬剤感受性 を調べた。その結果内膜における排出ポンプで あるMexA-Bと外膜蛋白であるOprMは共役的 に働いて薬剂を排出していることが明らかと なった。しかしながらMexA-B蛋白が欠失して も抗生物質の排出はある程度行われたが、一方 OprMが欠損すると薬剤の排出は極度に低下し た。これらの結果は排出蛋白が内膜と外膜で独 立に働き得ることを示唆すると共に、この排出 系が $\beta$ ラタム剤の排出をも行うことを説明す るものである。

\section{公開 S - 1}

腸管出血性大腸菌 $\mathrm{O} 157$ 感染症 の治療研究の展開

竹田多惠

国立小児医療研究センター 感染症研究部

今年の腸管出血性大腸菌 0157 ( 以下 0157 と 略す)の多発でいろいろなことを学んだが、治 療法の研究に焦点をあてて考察したい。0157 を摂取しても発症する頻度はせいぜい $20 \%$ 程 度で、かなりの人は無症状で経過する。問題は $5 \%$ 程度の患者に続発する溶血性尿毒症症候群 (HUS) で、この重症化の主要因がベロ毒素であ ることは動物実験の成績からも明確である。細菌 毒素による重要な疾患として破傷風、ジフテリア、 ボツリスムなどがあるが、これらはトキソイドワ クチンや血清療法で良い成果があげられており、 0157 同様のストラテジーが有効と考えてま ちがいない。現在考えられている特異的治療法は、

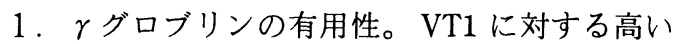
中和抗体は存在するが、VT2 抗体はなかった。 2. カナダで開発中の吸着剤の導入。Gb3 をク ロモソルブに結合させたもので、食事に混ぜて 経口投与し、VT を腸管内で特異的に吸着さ せる。本剤は腸管内の様な夾雑物の多いところ でも VTを特異的に吸着することができる。

3. ヒト型モノクローナル抗体の調製。マウスの モノクローナル抗体をヒト型に変える方法と、 患者リンパ球から調製する方法を進めている。

しかし、いずれの方法が開発されたとしても、 感染を迅速に診断し、早急に治療を開始すること が重要である。一旦、標的細胞に結合した毒素は、 その作用を止めることは今の知識では不可能であ る。米国西海岸で 11 月はじめにリンゴジュース による集団、スコットランドで 11 月末に精肉店 に絡んだ 5 名の死者を出すなどの集団事件が報道 され、0157 感染症は年間を通じ、しかも国際 的な問題として取り組むことが求められている。 
公開 S - 2

腸管出血性大腸菌感染症の臨床

五十嵐隆（東大分院小児科）

腸管出血性大腸菌(EHEC)感染症の榎床像につ き解説する。EHEC感染症のほとんどは下痢症 で、それに引き綂いて血液、腎、媨などの菉々 な障害を引き起こすことを特徽とする。

(i) 下利症

本症の初発症状であり、EHECを経口提取 3-7 日後に下溯が発症する。患者の 1 割に軽度の発 熱を認める。下疬症患者の半数か血便を呈す る。下疮の持続期間は7-14日で、まれに虫垂炎 や直閶脱を合併する。重症例は消化管壊死、賽 孔などを発症し、死因となる。

(ii) 溶血性尿毒洊庭候群(HUS)

下開開始7日頃から溶血性蕒血、血小板減少、 監機能低下（急性觜不全）が出現する病態であ る。EHEC感染の幼稚国児 (1990年浦和市) の 8.0\% 小学生 (1996年堺市) の1.6\%がHUSを 発症した。血液異常所見は一過性で多くは2-3 週間で自然回復する。ヘモグロビン尿と赤血球 尿の混在による赤色尿、掻白尿、高 $\beta_{2}-$ ミクロ グロブリン尿となる。急性腎不全の多くは7-10 日間で回復するが、的 3 割に透析庴法が必要と なる。通切な水電解筫の管理と透析旗法により 急性腎不全による死亡は今日激隇した。

(iii) 神経症状（中枢神経障害）

HUSの3-4割に神経症状（密識状態の低下、

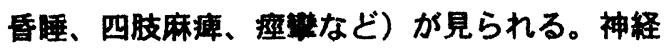
症状の多くはHUSの診断がつく時期に出現する が、重症例ではHUSの㱏状が出そろわない早期

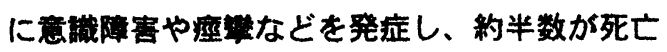
する。今日而症の中枢神経障害はEHEC感染の最 も扂険な合併应であり、死亡例の大半を占め る。有効な治橑法はない。死亡率は幼稚国坚 （1990年浦和市）では1.1\% 小学生（1996年 堺市）では0.03\%であった。
公開 S - 3

日本の集団発生例と分子疫学

○寺嶋 淳、和田昭仁、稲垣善茂、泉谷秀昌、 伊藤健一郎、田村和満、渡辺治雄

（国立子研・細菌部）

1996 年の腸管出血性大腸菌(EHEC)O157:H7 による集団発生は日本全国におよび散発事例も含 めた患者数は 9,000 人を越えた。我々はこれらの 分離菌株についてパルスフィールドゲル電気泳動 (PFGE)及び Random Amplified Polymorphic DNA(RAPD)-PCR によりその近縁度を調べ、 以下の結果を得た。

大きく分けると PFGE では 6 タイプ、RAPD で は 2 タイプに分けられ、PFGEと RAPD の分類は 相関が見られた。EHEC 0157:H7 の有する志賀 毒素遺伝子(stx)のタイプはstx1, stx2 共に陽性お よび stx2 のみ陽性の菌株が 9 割以上であった。 PFGE タイプI、RAPD タイプIに属する菌とし て、岡山県（邑久町、新見市）、広島県、岐皁県、 愛知県、福岡県、大阪府河内長野市で 5 月、 6 月 に発生した集団事例由来の菌が近縁度が高く、こ の時期以降の散発例からも全国的に同型のパター ンを示す菌が分離されている。大阪府堺市で 7 月 に発生した集団事例および京都府、大阪府羽曳野 市、和歌山県での集団事例は PFGE タイプ I、 RAPD タイプ II に分類される菌で引き起こされ ており、同時期に近畿地区で多く見られた散発事 例からの分離株で同型のパターンを示す菌が多数 あることが明らかになった。7月に群馬県で発生 した集団事例由来の菌は上記とは異なる PFGE タイプIVのパターンを示し RAPD タイプ II であ った。この型に属する菌株もまた、他の地域での 散発事例から分離されている。従って、多種類の タイプの菌が全国的に分離されており、集団事例 分離株のタイプも多岐にわたることが明らかにな った。 
公開 S - 4

腸管出血性大腸菌感染症の世界の現状

甲斐 明美 （都立衛研・微生物）

腸管出血性大腸菌O157による感染症は,1996年 5 月下旬以降全国的に猛威を振い，12月25日現在, 患者数は9,336人，死者は 11 人に及んでいる。

本菌は，1982年，米国で発生した集団事例で最 初に発見されたが，それ以来，本菌感染症は北米 やヨーロッパ諸国を中心に数多く発生している。 特に米国や英国では，本菌感染症は 'Emerging Infectious Disease’ とされ，緊急監視が必要な 感染症としてその予防対策が重要視されている。 本シンポジウムでは, 本菌感染症の世界の現状に ついて紹介したい。

米国：1982年に0157による最初の集団事例が 発生して以来既に14年以上が経過したが，これま でに 100 例以上の集団例が報告されている。特に, 1994年以降の増加は著しく, 年間当りの集団事例 の発生数は，1992年には 4例であったのに対し， 1993年及び1994年には30例あるいはそれ以上にな っている。そして現在,年間 20,000 人の患者と 100 人の死者が発生しているものと推定されている。

カナダ：1982年以来O157による下痢症が多発 しているカナダにおいても，これまでに報告され ている0157による集団下痢症は少なくとも26事 例, 散発事例を含む検出症例数は, 1988年に1,885 例，1989年に 2,384 例で，年々増加㑯向にある。

英国：0157検出数は1980年代初期には年間10 例以下であったが,1988年以降急増し，1994年には 656例に及んだ。 Engl and and Walesの報告におい ても1994年のヒトからの0157検出数は400例であ ったのに対し,1995年にはその倍の800例が報告さ れている。また,集団事例も1989年〜'91年の 3年 間には7事例(患者数76人)であったのに対し,1992 年〜'94年の 3年間には 18 事例(患者数 173 人)と急 增している。

これら諸外国の本菌感染症の発生状況とその原 因食品あるいは感染源等についても紹介したい。
公開 S - 5

腸管出血性大腸菌感染症への行政的取り組み

堺 宣道（厚生省食品保健課長）

平成 8 年 5 月 28 日、岡山県邑久町の小学校で集団 下痢症が発生し、調査の結果、病原性大腸菌O-15 7 に污染された学校給食による集団食中毒と判明した。 その後も Oー157 による集団・散発事例の発生が相 次ぎ、 7 月 13 日、大阪府堺市において、有症者累計 5499 名に上る大規模なOー157による集団食中 毒が発生した。堺市に対して、大阪府及び厚生省の協 力が必要であったことから、「病原性大腸菌O-15 7 食中毒原因究明三者連絡会議」が設置され、協力し て原因究明等が進められた。疫学調查等の結果、9月 26 日「特定の貝割れ大根がもっとも可能性が高いと 考えられる」とする最終報告がまとめられた。

また、政府においては、厚生省に「病原性大腸菌 $\mathrm{O}$ - 157 対策本部会議」、内閣に「病原性大腸菌 $\mathrm{O}-$ 157 対策関係閣僚会議」が設置され、関係省庁が連 絡して必要な対策を講じる体制を整備した。

厚生省は、全国の都道府県等に食中毒発生防止の徹 底及び学校給食施設衛生管理の緊急指示の指示、現地 への専門家の派遣、食中毒予防・診断治療方法等に関 する情報提供、「腸管出血性大腸菌に関する研究班」 による調查研究、腸管出血性大腸菌の指定伝染病への 指定等の対策を実施した。

その後、発生は減少したが、例年食中毒が沈静化す る秋に入っても発生するなど、依然予断を許す状況に ない。また、その後の調查においても、保健所等に指 導にも関わらず、学校給食施設に改善されない衛生管 理上の多くの問題があることも明らかとなった。

このため、今後厚生省では、集団給食施設の衛生管 理マニュアル、発生時の調查及び対応マニュアル等を 作成し、関係省庁とも連携して発生防止に万全を期す とともに、これまでのデータ等を生かした診断・治療 方法に関する研究やべ口毒素の中和等による重症化防 止方法に関する研究を推進することとしている。 